\section{Investigation of the Capacity of Social Innovation to Create Rural Development and Social Change within the Scope of Tourism Industry: The Case of Kuyucak Village, Isparta}

\author{
Nedim Yüzbaşığlu ${ }^{1}$, Pınar Çelik Çaylak ${ }^{2}$ and Yunus Topsakal ${ }^{3, *}$ \\ ${ }^{1}$ Prof. Akdeniz University,Turkey nedimy@akdeniz.edu.tr \\ ${ }^{2}$ Dr. Akdeniz University, Turkey pinarcelik@akdeniz.edu.tr \\ ${ }^{3}$ Dr. Adana Alparslan Türkes Science and Technology University, Turkey, topsakal.yunus@gmail.com
}

\begin{abstract}
.
The research aims to contribute to the social innivation literature in the context of tourism industry. Social innovation has a positive effect on economic development, rural and urban development, and combating poverty, reducing unemployment rate, community-based projects and social change. The main research topic of the study is to examine the social innovation in the tourism firms which operated by local people in Kuyucak village and to determine the capacity of social innovations to create rural development and social change. Qualitative methods were used as the research method. The interviews were based on the sixstage social innovation spiral model. Various interviews were made with tourism firms established by local people. Observations were made in tourism firms established by local people in the region. The data obtained as a result of semi-structured interviews with tourism firms established by local people and data were subjected to content analysis.
\end{abstract}

Keywords: social innovation, rural development, social change, tourism 


\section{Introduction}

Innovations made by organizations to protect the existing competitive advantage, to increase and sustain it, and to increase efficiency and effetiveness within the organization, are directed towards environment, social and personnel. Innovations that are included in this scope and which can be a solution to the problems of unemployment, environmental pollution and poverty to the local community and cause local development and consequently social change are called social innovation. According to Buchegger \& Ornetzeder (2000), social innovations should meet the needs of the local community, raise the standards of living in a sustainable way, increase the abilities of individuals and groups, and increase the production capacity of organizations. At the macro level, social innovation eliminates inequalities, causes social change and provides sustainable development (Buchegger \& Ornetzeder, 2000). Forprofit and non-profit organizations trigger social changes with their personnel, community and environmental innovations. Social innovations cause social change as they change the economy of the local community. The local community is now transformed into entrepreneurs in its environment, thereby ensuring rural and regional development.

Organizing environmental, community and personnel innovations in the places where organizations operate, and engaging in social innovation activities is important for organizations social change, local community benefit and social development In addition, local community can turns into an entrepreneur and social change is observed in the local community. Theoretical studies have been conducted on the role of entrepreneurs in social innovation. In addition, it is necessary to pioneer similar social innovations in other regions by analyzing case studies in social innovations that cause regional development, social change and are carried out by local communities as entrepreneurs. The main objective of the research is to examine social innovation in the tourism firms, established and operating by local people in Kuyucak village and to examine the capacity of social innovation to create rural development and social change.

\subsection{Literature Review}

The subject of social innovation has begun to enter the literature in the last two decades and has reached its peak with the "International Handbook on Social Innovation" published in 2013 (Moulaert et al., 2013). Social innovation in North America is often accomplished through public sector initiatives and sometimes public-private sector initiatives. In the European context, the concept of social innovation generally means private initiatives to solve private problems and meet special needs (predominantly social needs and security) (Leadbeater, 1999).

International Handbook of Social Innovation has defined social innovation as improving welfare through the improvement of social relations and community improvement processes (which is a society, nation, world goal that socially covers more inclusive and universal rights) (Moulaert et al., 2013). The European Union, which supports social innovation with various projects, has defined social innovation as new ideas (products, services and models) that create new social relationships or collaborations and meet social needs more effectively than their simultaneous alternatives (Dro et al., 2011). . According to Groot \& Dankbaar 
(2014), this definitions in innovation textbooks are similar, there is only the addition of "social" adjective. The definition of "new social relations" is more like the definition in innovation textbooks. In addition, in innovation textbooks, it means that social innovation is realized by "third sector" organizations, which are used in the sense of non-profit organizations and also non-public institutions (Groot \& Dankbaar, 2014). However, reports published by the European Commission show that the meaning of social innovation is not only used for third sectors (BEPA, 2011; Dro et al., 2011). It is suggested by the European Commission BEPA report (2011) that social innovation can be launched not only in non-profit sectors but also in all economies, including the public and private sectors.

Social innovation, as a field of study, does not have a long history in the field of social sciences. However, it can be said that it is true that social innovation as a phenomenon is constantly present in the evolution of human communities (van Langenhove, 2001). In practices, habits, and institutions such as money, voting rights, laws, and the modern state, social innovation has certainly existed for certain periods of time. However, the concept of social innovation in public administration Guth, 2005), social movements (Henderson, 1993), management (Clements \& Sense, 2010), social psychology (Marcy \& Mumford, 2007), economics (Pol \& Ville, 2009) and social entrepreneurship (Lettice and Parekh, 2010) have emerged in recent years. In the last two debate, social innovation in management studies has been seen in different fields such as social entrepreneurship, social movements and social economy (Henderson, 1993). Therefore, there are various definitions of social innovation in the literature. These various definitions that have been made depend on the discipline of social innovation. In their study, Choi \& Majumdar (2015) classified the definition of social innovation from seven different perspectives.

- Social Innovation from a Sociological Perspective: Social innovation is considered as social practices and structures that lead to social change and evolution from a sociological perspective. From this perspective, Zapf (1991) defined social innovation as new organizational strategies, new regulations, new production methods and new life arrangements that change the direction of social change.

- Social Innovation from Creativity Research Perspective: The creativity perspective focuses on the impact of social innovation on the change of social interaction in social systems, as in the social perspective. But the point of view of creativity emphasizes the goal-oriented aspect of social innovation. From this perspective, Mumford \& Moertl (2003) defined social innovation as developing and implementing new ideas about people and their interactions in the social system.

- Social Innovation from a Welfare Economy Perspective: According to this perspective, an innovation must improve the quality of life in order to become a social innovation (Pol \& Ville, 2009).

- Social Innovation with a Practical Perspective: This perspective consists of studies that are generally theoretical. From this perspective, according to Mulgan (2007), social innovations can be developed and applied by different actors such as individuals, organizations, and innovation businesses. 
- Social Innovation from a Social Psychology Perspective: From this perspective, social innovation is explained by human values such as compassion, affection, humility and shared emotions.

- Social Innovation from a Regional Development Perspective: From this perspective, social innovation has been evaluated within the scope of the labor market, education system, and socio-cultural life. Moulaert et al. (2005) argued from this perspective that social innovation is three-dimensional: content dimension, process dimension and empowerment dimension.

- Social Innovation from an Entrepreneurship Perspective: From this perspective, social innovation leads to social change. Definitions made from this perspective are made from the Schumpeter perspective. It is emphasized that social innovation is realized with the help of social entrepreneurs (for-profit or non-profit organizations). From this perspective, social innovation is new combinations such as new ways of production that create social change, new personnel practices, new social practices, new environmental practices.

According to Howaldt \& Schwarz (2010), social innovations are elements or pre-requisites for social change. Technical innovations are also elements of social change. However, they are not like social innovation. Social change, which deals with the socio-technological point of view rather than technical innovations, only follows technical innovations. On the contrary, social innovation shapes the elements and sub processes of social change at micro, meso and macro levels. In the process of spreading social innovation, it can use technical structures and existing technologies (internet) without losing its social innovation feature. Social innovations can have both targeted, deliberate, planned and predicted effects and unintentional, unplanned and unpredictable effects simultaneously (Gillwald, 2000).

Generally, the terminological and functional bond applied in the relationship between social change and social innovation does not predict that there is more demand for social innovation than social change (Kesselring \& Leitner, 2008). First of all, social change should not be seen as the only determinant of social innovation due to its relationship with social change. However, there is a clear relationship in some areas between the two. Social innovations are not sufficiently different from other innovations and social change in terms of functionality. The functional difference between social change and social innovation lies behind their relationship with planned and coordinated actions (Greenhalgh et al., 2004). While social change is unintentionally defined as the process of change in social structures such as society's institutions, cultural structures and social actions (Zapf, 1991), social innovations are intentional and purpose-oriented to make new social practices in certain areas.

\section{Methods}

The main aim of the research is to examine social innovation in tourism firms established and operating by local people in Kuyucak village and to determine the capacity of social innovation to create rural development and social change. Since the aim of this study is to focus on the social innovation in the tourism firms which operated by local people in Kuyucak village and to determine the capacity of social innovations to create rural development and social change, it has been decided that qualitative research methods are appropriate. Because in qualitative research, researchers try to understand the meanings that people place on the 


\section{$3^{\text {rd }}$ International Conference on BUSINESS, MANAGEMENT \& ECONOMICS}

6 - 8 MARCH 2020

BUDAPEST, HUNGARY

facts by examining the facts in their natural environment. It is stated that qualitative studies emphasize processes and meanings, emphasize the socially structured nature of reality, the close relationship between the researcher and what is investigated, and the situational constraints that shape the research, and seek answers to questions that emphasize how social experience is created and gained meaning (Denzin \& Lincoln, 1994). Interview technique was used for the purpose of the study. Interviews are known as a frequently used data collection method in qualitative research (Denzin, 2001).

Interviews are considered important because people's feelings, thoughts and worldviews cannot be observed (Merriam \& Tisdell, 2015). In this study, data were collected by interview with 7 tourism firms which operated by local people in Kuyucak village. Demographic characteristic of the interviewees is given in Tab. 1.

Table 1. Demographic Characteristic of Interviewees

\begin{tabular}{|l|l|l|l|}
\hline Age & Gender & Education & Field of Activity \\
\hline 66 & Women & Primary School & Lavender cultivation, F \& B \\
\hline 54 & Women & Primary School & Lavender cultivation, lavender product sales \\
\hline 37 & Women & High School & Lavender cultivation, lavender product sales \\
\hline 51 & Women & Primary School & Lavender cultivation, lavender product sales \\
\hline 47 & Men & Middle School & Lavender cultivation, lavender product sales \\
\hline 50 & Women & Primary School & Lavender cultivation, F \& B \\
\hline 59 & Men & Bachelor Degree & Lavender cultivation, Accommodation \\
\hline
\end{tabular}

As part of the interviews, 22 questions were asked to the participants. the participants were named as A1-A7 in the analyzes.

\section{Results and Discussion}

One of the participants has been living in Kuyucak village for 1 year, while the other participants have been living in Kuyucak village for 54, 37, 50, 15, 47 and 50 years, respectively. Participants cultivate lavender between 1 and 45 years. There is a "LavenderScented Village" project in Kuyucak village. While 5 of the participants are aware of this project, 2 of them are not aware of this project. Since the activity in Kuyucak village is included in the scope of eco tourism / rural tourism, the participants were asked whether they have any knowledge about eco tourism / rural tourism. While 2 of the participants have information about eco tourism / rural tourism, 5 of them do not.

The important answers given by the participants to the question "did the Lavender-Scented Village Project cause tourism mobility?;

- "Lavender has been produced in our village for 40 years, but 4 years ago with the promotion from the internet tourist start to visit village" (A1)

- "Tourists started to visit the village with the project" (A2)

- "It had a lot of impact. It caused some surprising tourism growth" (A4)

- "The project has a lot of contribution, so many tourists have visit village with the project" (A6) 


\section{BUSINESS, MANAGEMENT \& ECONOMICS}

- "After the project, tourists started to come to the village. No one knew about our village before, now everyone comes to take photos" (A7)

According to interviewa, new job opportunities were created in the village of Kuyucak with the Lavender-Scented Village project. Participants generally cultivate lavender, sell lavender products (shampoo, cream, soap, cologne, etc.) to tourists, and sell food and beverage products such as pancakes in certain places. One of the participants even provides accommodation in village houses and employs 20 people.

All of the participants stated that they had already cultivate lavender before the LavenderScented Village project. One of the participants was trained for cultivate lavender, while the others did not receive any training. It was stated that lavender products sold in the village were purchased from the factory. Only one participant received training on the production of products sold from lavender to tourists. This participant stated that he had received training in the cooperative in the village regarding the products. These participants expressed their educational activities as "we made an eye-patch for sleep, we put lavender on the gift making, we learned how to do this in cooperative education" (A7).

Some statements about what has changed in the village of Kuyucak with the LavenderScented Village project are as follows;

- "When the village was promoted with the project, tourists started to come and opened a new workplace” (A4)

- "There have been good changes. Cafes opened and job opportunities were available at lavender product sales stands. We are also pleased with the tourists coming to the village" (A6)

- "A lot has changed in the trainings provided. We learned about different uses of lavender. We used to make only lavender soap and oil in the village, now there is even lavender ice cream in the village" (A7)

Almost all families cultivate lavender in Kuyucak village. The reason for this is that cultivating lavender in the village is scarcely due to the climate. In addition, it was determined that it is not possible to cultivate anything other than lavender in the village due to the climatic conditions. Lavender cultivation in the village is made with spouses and children, all family members. Lavender cultivation period is 2 months. According to the participants, cultivation and harvesting lavender is an effortless process. For the remaining 10 months, roses, beekeeping and livestock activities are carried out in the village. It was stated that lavender honey obtained by beekeeping by the participants also attracted tourists attention in the village.

It was determined that there was a partial change in the status / social status within the family with the Lavender-Scented Village project. Those engaged in lavender activity stated that they are more known and have status in the cooperative. It has been stated that the family budgets have increased slightly due to the new use of the tourist potential of the village with lavender. It is believed that with the increase in the variety of lavender products and the number of tourists in the future, local people will earn more income from lavender activities. 


\section{$3^{\text {rd }}$ International Conference on BUSINESS, MANAGEMENT \& ECONOMICS}

The three important answers to the question of "do you believe that the place of women and young people living in the village of Kuyucak will be strengthened by rural tourism?" is;

- "I definitely believe they are getting stronger culturally and economically" (A4)

- "They are strengthening economically" (A6)

- "Some women in the village earn money by opening a stand in front of their homes in some cooperatives. Our youth are staying in the village because it is crowded in the summer and they don't go out" (A7)

It was stated that only new roads and asphalting of existing roads were carried out as a public service with the increase of tourism mobility in Kuyucak village. It is stated that there is no area in the village that tourists can see outside of the lavender fields and green areas should be increased in the village by afforestation. Apart from that, the rose (rose products) and lavender honey, which are local in Kuyucak village, should also be promoted as tourist attractions.

It has been determined that the local people in the village of Kuyucak are satisfied with the tourists and their behave the tourists are friendly. Despite this, it was also stated by the participants that there are people who make opportunism in the village and increase the prices. It is thought that tourism does not have any cultural negative impact in the village, however may be in the long term. It was stated that as the number of tourists increases, the amount of garbage increases.

\section{Conclusion}

Social innovation issue, which drive social change through local development investigated in Kuyucak Village, Isparta, Turkey. The village of Kuyucak has started to attract tourists with lavender in recent years. Realizing this, the villagers started to cultivate lavender for tourism. Local people have started to sell lavender products to tourists, to organize tour to lavender fields, offer food and drink, and even some villagers offer accommodation in their homes. Considering the results of the study and field observation, the following suggestions were proposed;

- Since lavender cultivation increases, its value decreases, prices should not decrease much,

- There should be variety in meals,

- Business should be diversification,

- Village people should be informed about tourism,

- The environmental change of the village should be made,

- Paint of the houses in the village should be renewed,

- Parking places should be taken at the entrance of the village,

- The infrastructure problems of the village should be eliminated,

- Road and direction signs should be increased, 


\section{$3^{\text {rd }}$ International Conference on BUSINESS, MANAGEMENT \& ECONOMICS}

- Everyone should not do the same job. While differentiating, some sell lavender products, some sell food, some take tourists in the fields,

- Tours should be organized with tractors,

- Kuyucak village should be promoted and projects should be increased,

- Local people should be guided as investment,

- Places related to accommodation should be made. Because daily tours is not enough. Photographers who want to stay 3-5 days in the future may want to visit the village,

- Tourism period is 2 months. Roses and rose products in the village may also be longer if promoted.

\section{Acknowledgment (TNR 12pt. bold)}

This paper is an output of the science project and has been funded by Akdeniz University Scientific Research Project. (Project Number: SBA-2018-3424)

\section{References}

[1] BEPA (Bureau of European Policy Advisers) (2011). Empowering People, Driving Change: Social Innovation in the European Union, Luxembourg: Publications Office of the European Union.

[2] Buchegger, B. and Ornetzeder, M. (2000). Social Innovations on the Way to Sustainable Development, Proceeding of 3rd Biennial Conference of the European Society for Ecological Economics Transitions Towards a Sustainable Europe Conference. Vienna, pp. 1-11.

[3] Choi, N. and Majumdar, S. (2015). Social Innovation: Towards a Conceptualization, India: Springer, pp. 7-33.

[4] Clements, M. D. J. and Sense, A. J. (2010). Socially shaping supply chain integration through learning, International Journal of Technology Management, vol. 51, issue. 1, pp. 92105.

[5] Denzin, N. K. (2001). The reflexive interview and a peformative social science, Qualitative Research, vol. 1, issue. 1, pp. 23-46.

[6] Denzin, N. K. and Lincoln, Y. S. (1994). The Landscape of Qualitative Research: Theories and Issues, Thousand Oaks, CA: Sage.

[7] Dro, I., Therace, A. and Hubert, A. (2011). Empowering People, Driving Change: Social Innovation in the European Union. Brussels: European Commission.

[8] Gillwald, K. (2000). Concept of Social Innovation. Berlin: Science Center for Social Research.

[9] Greenhalgh, T., Robert, G., Macfarlane, F., Bate, P. and Kyriakidou, O. (2004). Diffusion of innovations in service organizations: systematic review and recommendations, The Milbank Quarterly, vol. 82, issue. 4, pp. 1-37. 


\section{$3^{\text {rd }}$ International Conference on \\ BUSINESS, MANAGEMENT \& ECONOMICS}

[10] Groot A. and Dankbaar, B. (2014). Does social innovation require social entrepreneurship?, Technology Innovation Management Review, vol. 4, pp. 17-26.

[11] Guth, M. (2005). Innovation, social inclusion and coherent regional development: a new diamond for a socially inclusive innovation policy in regions, European Planning Studies, vol. 13, issue. 2, pp. 333-349.

[12] Henderson, H. (1993). Social innovation and citizen movements, Futures, vol. 25, issue. 3 , pp. 322-338.

[13] Howaldt, J. and Schwarz, M. (2010). Social Innovation: Concepts, Research Fields and International Trends, Dortmund: Sozialforschungsstelle.

[14] Kesselring, A. and Leitner, M. (2008). Social Innovation in Business. Wien: Social Innovation Center.

[15] Leadbeater, C. (1999). Living on Thin Air. London: Penguin Books.

[16] Lettice, F. and Parekh, M. (2010). The social innovation process: themes, challenges and implications for practice, International Journal of Technology Management, vol. 51, issue. 1, pp. 139-158.

[17] Marcy R. T. and Mumford, M. D. (2007). Social innovation: enhancing creative performance through causal analysis, Creativity Research Journal, vol. 19, issue. 2, pp. 123140.

[18] Merriam, S. B. and Tisdell, E. J. (2015). Qualitative Research: A Guide to Design and Implementation, 4th ed. San Francisco, CA: Jossey-Bass.

[19] Moulaert, F., MacCallum, D., Mehmood, A. and Hamdouch, A. (2013). The International Handbook on Social Innovation, Cheltenham: Edward Elgar.

[20] Moulaert, F., Martinelli, F., Swyngedouw, E. and Gonzalez, S. (2005). Towards alternative model(s) of local innovation, Urban Studies, vol. 42, issue. 11, pp. 1969-1990.

[21] Mulgan, G. (2007). Social Innovation: What it is, Why it Matters and How it can be Accelerated. Oxford: Said Business School.

[22] Mumford, M. D. and Moertl, P. (2003). Cases of social innovation: lessons from two innovations in the 20th century, Creative Research Journal, vol. 15, issue. 2, pp. 261-266.

[23] Pol, E. and Ville, S. (2009). Social innovation: buzz word or enduring term?, Journal of Socio-Economics, vol. 38, issue. 6, pp. 878-885.

[24] van Langenhove, L. (2001). About Innovating the Social Sciences and Innovation in Society, Paris: OECD Publishing, pp. 29-34.

[25] Zapf, W. (1991). The role of innovations in modernization theory, International Review of Sociology, vol. 2, issue. 3, pp. 83-94. 